\title{
Potentially Probiotic Bacteria Isolated from Preparation Stages of Kermanshahi Traditional Fat
}

\author{
Ramin Abiri ${ }^{1}$; Minoo Aliabadi ${ }^{2}$, Sepideh Kadivarian ${ }^{2}$, Soroush Borji ${ }^{2}$, Jale Moradi ${ }^{3}$, \\ Amirhooshang Alvandi 3 iD
}

1. Fertility and Sterility Research Center, School of Medicine, Kermanshah University of Medical Sciences, Kermanshah, Iran

2. Student Research Committee, and Department of Microbiology, School of Medicine, Kermanshah University of Medical Sciences, Kermanshah, Iran

3. Medical Technology Research Center, Research institute for Health Technology, School of Medicine, Kermanshah University of Medical Sciences, Kermanshah, Iran

\subsection{9/ijmm.15.3.352}

\section{ABSTRACT}

Background and Aim: Dairy fermented foods such as yogurt, cheese, fermented milk, butter milk, curd, butter and ghee are used as major diet ingredients in west of IRAN, such as Kermanshah province. Ghee (Kermanshahi traditional oil or roghane heiwâni) is traditionally produced from butter milk of yoghurt after fermentation. Review of the literature yielded no study on isolating probiotics from Kermanshahi traditional oil preparation stages. Therefore, purpose of this study was just to focus on isolating and identifying lactic acid bacteria in these products using culture and PCR-sequencing methods.

Materials and Methods: Fifteen samples from each dairy products including yogurt, butter and Kermanshahi traditional oil were collected in Kermanshah province, Iran. Each sample was diluted, homogenized, and cultured on selective medium for growing of lactic acid bacteria. 16SrRNA gene sequences analysis was carried out for final confirmation of these isolates.

Results: After culturing of samples on MRS and M17 under aerobic and anaerobic condition, a total of 78 strains of bacteria were isolated and identified by conventional biochemical tests. The frequency of bacteria in all isolates (78) were $48.71 \%$ for Lactobacillus, 33.33\% for Streptococcus, 6.41\% for Enterococcus and 6.41\% for Bacillus. Lactobacillus, Streptococcus, Enterococcus, and Bacillus genus, were isolated from $84.44 \%, 57.78 \%, 11.11 \%$ and $15.56 \%$ of all three kind of samples, respectively.

Conclusion: Based on our findings, Lactic acid bacteria and other potentially probiotic microorganisms are present in Kermanshahi traditional oil. Of course, the potential probiotic properties of these isolates and impact of consumption of Kermanshahi traditional oil containing those on human health need to be analyzed more. By proving the presence of probiotic bacteria in Kermanshahi oil, it may be falls in the category of functional foods.

Keywords: Dairy, Kermanshahi traditional oil, Lactic acid bacteria, PCR sequencing, Probiotics

Received: 2020/05/02; Accepted: 2020/12/05; Published Online: 2021/06/28

\begin{tabular}{|c|c|}
\hline Corresponding Information: & $\begin{array}{l}\text { Amirhooshang Alvandi, , Mashhad Branch, Razi Vaccine and Serum Research Institute, Agricultural Research, Education and } \\
\text { Extension Organization (AREEO), Mashhad, Iran. } \\
\text { Email:ah_alvandi@kums.ac.ir }\end{array}$ \\
\hline & material just in noncommercial usages with proper citation. \\
\hline
\end{tabular}

Use your device to scan and read the article online

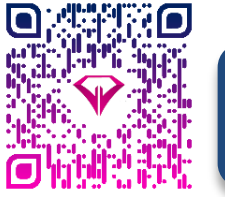

Abiri R, Aliabadi M, Kadivarian S, Borji S, Moradi J, Alvandi A,. Potentially Probiotic Bacteria Isolated from Preparation Stages of Kermanshahi Traditional Fat. Iran J Med Microbiol. 2021; 15 (3) 352-360

\section{Download citation: BibTeX | RIS | EndNote | Medlars | ProCite | Reference Manager | RefWorks}
Send citation to:

\section{Mendeley}
2 Zotero
(B) RefWorks 


\section{Introduction}

According to the definition by the world health organization (WHO) and food and agriculture organization (FAO), probiotics are live non-pathogenic microorganisms that have beneficial effects on the health of human if consumed sufficiently (1). A main group of these microorganisms is lactic acid bacteria (LAB) that are used as starter for dairy products. Probiotic strains of LAB have antioxidant, anticancer and antimicrobial potential effects. Moreover, it has been proved that probiotic bacteria can reduce serum cholesterol, relieve lactose intolerance, and stimulate the immune system leading to the stability of the microbiota (2). LAB that are associated with fermented foods include some species of Carnobacterium, Enterococcus Lactobacillus, Lactococcus, Leuconostoc, Oenococcus, Pediococcus, Streptococcus, Tetragenococcus, Vagococcus, and Weissella genera (3).

Fermentation is a frequently used food processing technique worldwide. There are many locally produced fermented foods (4) (5), including various kinds of yogurt, cheese, fermented milk, butter milk, curd, and butter (5). Some evidences suggest traditional butter fat or Ghee is a fermented food and could contain different kind of LAB. Fermentation of milk to yoghurt is traditionally occurred by Lactobacillus bulgaricus and Streptococcus thermophiles at $40-45^{\circ} \mathrm{C}$. These bacteria, are not present in intestinal microbiota, are not $\mathrm{s}$ and cannot survive in the gut (6).

Changes that occur during milk fermentation by LAB enhance nutritional value of the product (7). Kermanshahi traditional oil, which is traditionally produced, serves as an imp ortant type of fat in the diet of some areas in Iran and other countries of the South Asia (8). It is known as yellow oil, Kermanshahi oil, Ghee, roghan-e heiwâni, or Kermanshahi traditional oil (9). First, yogurt is produced from milk by traditional methods, and then it is put in a Mashk (a large leather bag/a big waterskin). After this step, butter is separated from the tan (doogh), then transferred to a larger pot, and slowly heated, allowing the components to separate by density and the remaining is called roghan-e heiwâni. Studies have shown that changes traditionally occur in the preparation of butter and Kermanshahi traditional oil in fatty acid. Among the reasons of such changes, bacterial fermentation process for the preparation of products can be pointed out. In products like yoghurt, butter and Kermanshahi traditional oil, due to the function of bacteria, lactic acid is produced and environmental $\mathrm{pH}$ is reduced (10). Furthermore, changes occur in the fatty acid of these products. There has been no study on isolating probiotics from Kermanshahi traditional oil preparation stages. Therefore, our purpose in this study was to identify probiotic bacteria from these products using culture and PCR-sequen- cing. Recognizing and recording of these microorganisms can help to preserve biological sources.

\section{Materials and Methods}

The present study was conducted during the period from October to the end of November, 2015. A total of 15 samples from each dairy product including yogurt, butter and Kermanshahi traditional oil were collected from Kermanshah Province. The samples were collected in sterile bottles and kept cold until they arrived at the laboratory, where they were kept at $4^{\circ} \mathrm{C}$. Only samples have been prepared using traditional starter were included in the study to ensure the absence of commercial starters. Ten grams of each sample were homogenized with $90 \mathrm{~mL}$ sterile normal saline solution $(0.85 \%, \mathrm{w} / \mathrm{v})$ to make an initial dilution $\left(10^{-1}\right)$. An amount of $100 \mu \mathrm{L}$ from each diluted sample was then cultured on MRS Agar (Oxoid, CM0361) and M17 Agar (Oxoid, CM0785) containing $0.05 \%$ cysteine, and incubated in both aerobic and anaerobic conditions at $37^{\circ} \mathrm{C}$ for $48-72$ hours. All bacterial isolates were screened using colony morphology and gram staining, and final identification was carried out through PCR sequencing. Then, 4-5 colonies were selected from each plate. After subculture, DNA of each plate was isolated using the DNA extraction kit according to the manufacturers' instruction. The extracted DNA was stored at -20 until PCR implementation. The PCR technique was employed for the amplification of genus-specific target of Lactobacillus and Bifidobacterium of using specific primers and universal primer of $16 \mathrm{~S}$ rRNA gene previously described by Lauren et al. The primers used in this study are summarized in Table 1 (11). The PCR was performed in a total volume of $25 \mu \mathrm{L}$, containing $2.5 \mu \mathrm{M}$ dNTP mix, $2.0 \mathrm{mM} \mathrm{MgCl}_{2}, 0.5 \mathrm{U}$ Taq DNA polymerase, $0.5 \mu \mathrm{M}$ of each primer, and $2.5 \mu \mathrm{L}$ of each template DNA and 10X buffer. Standard strains, Lactobacillus delbrueckii (PTCC 1737) and Bifidobacterium bifidum, (PTCC 1644) were used as a positive control in each reaction. The PCR was performed under the following conditions: Denaturation for $5 \mathrm{~min}$ at $95^{\circ} \mathrm{C} ; 30 \mathrm{cycles}$ of $1 \mathrm{~min}$ at $94^{\circ} \mathrm{C}, 1$ min at $60^{\circ} \mathrm{C}$, and $1 \mathrm{~min}$ at $72^{\circ} \mathrm{C}$, as well as a final extension step of $7 \mathrm{~min}$ at $72^{\circ} \mathrm{C}$. The PCR products were analyzed by electrophoresis on a $1.5 \%$ agarose gel. The agarose gel was stained using ethidium bromide and visualized in gel doc. Visualization of 340 bp and 520 bp confirmed the Lactobacillus and Bifidobacterium genus, respectively. Finally, each sample with single band within $470 \mathrm{bp}$ was selected for $16 S r R N A$ sequencing. The nucleotide sequences of the 16SrRNA 'gene of all the isolates were analyzed and edited using Bioedit software. Similarity searching was conducted for each edited sequence for exact determination of genus and species of each isolate 
(http://www.ncbi.nlm.nih.gov/BLAST). All 16SrRNA sequences were submitted to the NCBI GenBank under the accession numbers KX951698.1 To KX951735.1, KX926497.1 to KX926536.1.

Table 1. primer sequences for PCR-based detection of probiotic bacteria

\begin{tabular}{|ccc|}
\hline Target & Primer Name & Sequence $\left(5^{\prime}\right.$ to $\left.\mathbf{3}^{\prime}\right)$ \\
\hline Universal primers 16SrRNA gene & $341-\mathrm{F}$ & CCTACGGGAGGCAGCAG \\
\hline Specific primers Lactobacillus 16SrRNA & $768-\mathrm{R}$ & GACTACCAGGGTATCTAATC \\
gene & Lact-F & AGCAGTAGGGAATCTCCA \\
\hline Specific primers Bifidobacterium 16SrRNA & Lact-R & ATTYCACCGCTACACATG \\
\hline gene & Bif- & GGGTGGTAATGCCGGATG \\
\hline
\end{tabular}

\section{Results}

Overall, 45 samples were cultured and 78 colonies were selected according to colony morphology. All the isolates were gram positive catalase and oxidase negative. The isolates were all confirmed using the PCR and sequencing targeted 16SrRNA gene. The result is shown in Figure 1 and Table 2. Several species were identified including Lactobacillus, Lactococcus, Enterococcus, Streptococcus and Bacillus from the samples. The result showed that Lactobacillus was the dominant flora of the existing probiotic microorganism in the samples. In the yogurt samples, the L. delbrueckii, Lactobacillus helveticus, Lactobacillus fermentum, Lactobacillus rhamnosus, Lactobacillus paracasei with Streptococcus thermophilus, Enterococcus faecium, Brevibacillus formosus and Brevibacillus agri species were isolated. Brevibacillus and $E$. faecium were isolated from the yogurt samples only. Also, Brevibacillus was isolated from two samples only. However, L. paracasei and L. rhamnosus were isolated from both the yogurt and butter samples. Several species of Lactobacillus, Enterococcus, Streptococcus, Lactococcus and Bacillus were also isolated from the butter samples. The most prevalent genus was $L$. delbrueckii, $L$. helveticus, $L$. paracasei, L. rhamnosus, and L. fermentum. Other bacteria that were isolated from the traditional butter samples with less frequency were Lactococcus lactis, S. thermophiles, Enterococcus feacalis and Bacillus cereus. Bacillus subtilis and Bacillus licheniformis were isolated only from the butter samples. The detailed results of the isolates are shown in the following Table 2. Some species of the Lactobacillus, Streptococcus and Enterococcus genus were present in Kermanshahi traditional oil, but in a small number. The Lactobacillus species included $L$. fermentum, $L$. delbrueckii, Lactobacillus casei and L. helveticus. S. thermophiles, Enterococcus feacalis, Enterococcus feacium and Enterococcus hirae were the other isolated species from Kermanshahi traditional oil. E. hirae, however, was isolated from a single Ghee sample. The frequency of probiotic bacteria in all the samples including local yogurt, butter and Kermanshahi traditional oil was \%84.44 for Lactobacillus, \%57.78 for Streptococcus, \%11.11 for Enterococcus and \%15.56 for Bacillus.

Table 2. probiotic species in collected samples

\begin{tabular}{|c|c|c|c|c|}
\hline Bacteria & $\begin{array}{c}\text { Bacteria isolated } \\
\text { Kermanshahi traditional } \\
\text { yogurt(n)\% }\end{array}$ & $\begin{array}{c}\text { Bacteria isolated } \\
\text { Kermanshahi } \\
\text { traditional butter(n)\% }\end{array}$ & $\begin{array}{l}\text { Bacteria isolated } \\
\text { Kermanshahi } \\
\text { traditional oil }(n) \%\end{array}$ & Total \\
\hline L. delbrueckii & (9) 60 & (6) 40 & (4) 26.67 & (19) 42.22 \\
\hline L. helveticus & (1) 6.67 & (4) 26.67 & (2) 13.33 & (7) 15.56 \\
\hline L. fermentum & (2) 13.33 & (2) 13.33 & (2) 13.33 & (6) 13.33 \\
\hline L. rhamnosus & (1) 6.67 & (1) 6.67 & 0 & (2) 4.44 \\
\hline L. paracasei & (1) 6.67 & (2) 13.33 & 0 & (3) 6.67 \\
\hline L. casei & 0 & 0 & (1) 6.67 & (1) 2.22 \\
\hline S. thermophilus & (11) 73.33 & (4) 26.67 & (11) 73.33 & (26) 57.78 \\
\hline Bervibacillus & (2) 13.33 & 0 & 0 & (2) 4.44 \\
\hline E. faecium & (1) 6.67 & 0 & 0 & (1) 2.22 \\
\hline E. faecalis & 0 & (1) 6.67 & (2) 13.33 & (3) 6.67 \\
\hline B. cereus & 0 & (1) 6.67 & 0 & (1) 2.22 \\
\hline
\end{tabular}




\begin{tabular}{|ccccc|}
\hline Bacteria & $\begin{array}{c}\text { Bacteria isolated } \\
\text { Kermanshahi traditional } \\
\text { yogurt(n)\% }\end{array}$ & $\begin{array}{c}\text { Bacteria isolated } \\
\text { Kermanshahi } \\
\text { traditional butter(n)\% }\end{array}$ & $\begin{array}{c}\text { Bacteria isolated } \\
\text { Kermanshahi } \\
\text { traditional oil (n)\% }\end{array}$ & Total \\
\hline L. lactis & 0 & (2) 13.33 & 0 & (2) 4.44 \\
\hline E. hirae & 0 & 0 & (1) 6.67 & (1) 6.67 \\
\hline B. subtilis & 0 & (1) 6.67 & 0 & (1) 6.67 \\
\hline B. licheniformis & 0 & (3) 20 & 0 & (3) 20 \\
\hline Total & (28) 100 & (27) 100 & (23) 100 & (78) 100 \\
\hline
\end{tabular}

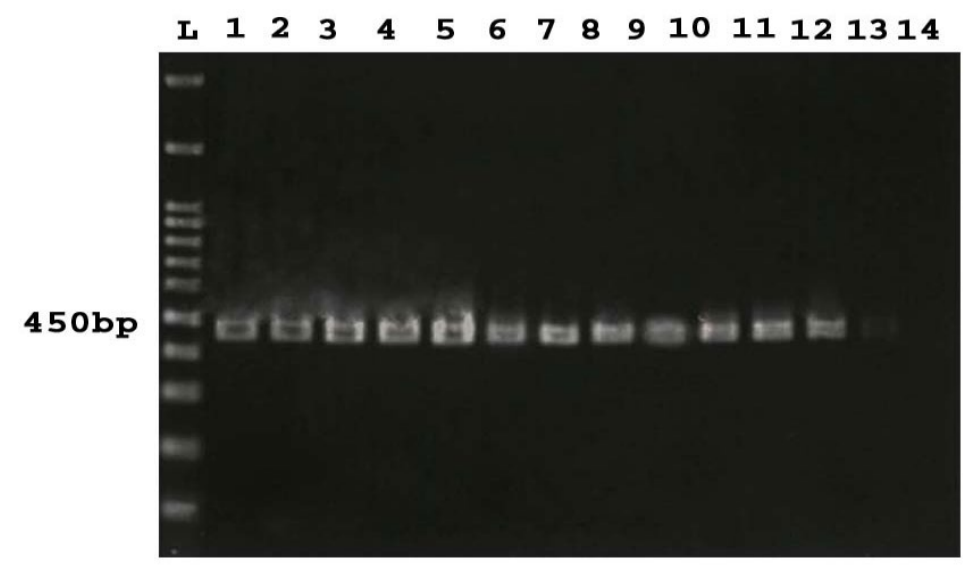

Figure 1. PCR products of 16SrRNA gene. L: 100 bp DNA Marker, 1-13: positive samples, 14: Negative control.

\section{Discussion}

Probiotic bacteria are non-pathogenic microorganisms known for their nutritional value and therapeutic effect as well as anti-microbial and anti-cancer effects on the host health. During the past two decades, these microorganisms have been isolated from variety of foods, especially dairy products. A wide range of dairy products such as fresh milk, yogurt, cheese, fermented butter and drinks containing $L A B$ can provide a good environment to support the growth and durability of probiotic microorganisms $(12,13)$. Many studies have been conducted on the isolation and identification of probiotic bacteria in various traditional dairy and fermented food products from all around the world (14). Lactobacillus plantarum, L. casei and Lactobacillus brevis were isolated from (traditional) yogurt and cheese by Ebrahimi et al. (15). Angmo et al. succeeded in isolating $L$. plantarum from Ladakh, a fermented vegetable product in India (1). Seven species of Lactobacillus and Bifidobacterium were isolated and reported studying traditional fermented dairy products in different regions of Russia (16). Moreover, numerous studies have indicated that isolated lactic acid bacteria from milk, cheese, fermented olives, kefir, sourdough of wheat and barley flour and other fermented products have the ability to inhibit the progress of some gastrointestinal diseases and have remarkable antibacterial properties compared with commercial strains (17-23). The most important lactic acid bacteria in the dairy industry are Lactobacillus, Streptococcus, Lactococcus and Enterococcus, and according to many studies, traditional fermented products are mostly dominated by Lactobacillus species (24). In the present study, Lactobacillus was the dominant $84.44 \%$ of all lactic acid bacteria. $L$. delbruekii and $S$. thermophilus were reported to be the most abundant probiotic bacteria in a Colombian study of dairy products using biochemical tests and 16SrRNA gene sequencing (25). Lactobacillus acidophilus and $L$. casei were reported as the most abundant isolate from dairy products of Bhardwaj in India $(26,27)$. L. paracasei and L. rhamnosus, two species that were isolated from yogurt and butter in present study, were used commonly as non-starter lactic acid bacteriain in dairy products. In some studies, L. paracasei has been isolated and identified from cheese and curd samples. Bervibacillus brevis and $E$. faecium were isolated from yogurt samples in this study. Although similar results have been reported (28), little information is available about their probiotic properties, which might even be regarded as contamination. Several reports have been presented in isolating (25) probiotic bacteria from local yogurt and butter separately. However, this study was the first to focus on isolation and identification of LAB from traditional Kermanshahi oil in various stages of development. Kermanshahi traditional oil is a common edible oil in parts of Iran 
including Kermanshah Province. It is an important consumable fat in people's diet in particular areas in Iran, and is traditionally prepared from yogurt (29). Bahrami et al. showed that fatty acids can change in traditional preparation of butter and Kermanshahi traditional oil. One of the reasons can be the fermentation process and lactic acid production by probiotic bacteria (10). Lactobacillus, Enterococcus, Lactococcus and Leuconostoc genera were isolated from traditional butter (Dhan), in a previous study (30). Thus, a probiotic bacterium in the preparation process of fermented products has been isolated according to traditional methods without the use of any commercial starter, which can be a valuable source of probiotic microorganisms. Hence, preparation of fermented products is being industrialized, making isolation and preservation of local strains particularly valuable. In this study, we attempted to isolate bacteria from local traditional yogurt, butter and Kermanshahi traditional oil. The result of this study revealed different isolated groups of probiotic bacteria from the samples of traditional yogurt, butter and Kermanshahi traditional oil, indicating that fermentation conditions were different in the samples. We found that $L$. delbruekii, $L$. helveticus, $L$. fermentum, and $S$. thermophilus were the pred-ominant isolates from the samples of traditional yogurt, butter and Kermanshahi traditional oil. Tarhana is a traditional fermented food mixture of wheat flour and yoghurt. During natural fermentation in Tarhana, LAB are dominant strains while $S$. thermophiles, $L$. delbrueckii and $L$. fermentum are dominant isolates (31). In our study, S. thermophilus and L. delbrueckii were the predominant isolates from the three samples. Fermentation of lactose by $L A B$ produce large amounts of lactic acid. Consuming ferm-ented Ghee with low $\mathrm{pH}$ increases absorption of a short chain of fatty acids essential for the optimum performance of the body (10). L. delbrueckii as a starter with the S. thermophiles species used in dairy industries has shown that all strains have high lactose activities that help to improve lactose digestion and eliminate symptoms of lactose intolerance (32). Lactobacillus delbrueckii and S. thermophiles elimin-ate cholesterols by binding to released bile acids, which can reduce the risk of cardiovascular diseases (33). L. helveticus can hydrolyze milk proteins and release bioactive peptides that are responsible for elevating IgA in the bronchial and intestinal regions and subsequently, for boosting mucosal immunity. As a thermophilic bacterium, L. fermentum is a non-starter lactic acid bacterium, which has considerable importance in fermented foods. It is isolated from different environments such as fermented milk. L. fermentum is one of the dominant Lactobacillus species in the intestinal tract and vagina in humans (34). In contrast to other studies, we isolated the Brevibacillus species only from yogurt
(13.33\% from yogurt), where Brevibacillus was also isolated from soil and milk. So far, this species has not been isolated from any food substance in Iran. However, at least in one study, Brevibacillus was used successfully as a starter for curd. It has been confirmed that Brevibacillus can be used as a suitable candidate in fermented milk production (28). The frequency of isolation was $6.67 \%$ for $L$. paracasei, $2.22 \%$ for $L$. casei and $4.44 \%$ for $L$. rhamnosus. These bacteria are frequently used as non-starter LAB in food and pharmaceutical industries. In addition to different species of Lactobacillus, S. thermophilus, L. lactis and $B$. cereus from traditional butter samples, E. faecium was isolated from two samples of traditional butter and oil in the present study. Bacillus strains are highly resistant to physical and chemical conditions due to spore formation, and are widely used as probiotics. $L$. lactis isolated from traditional butter in the present study has been indicated as a probiotic bacterium, and its antibacterial effect has been proven against pathogenic bacteria by Garsa earlier in a research (35). The presence of Enterococcus hirae and Enterococcus faecalis in traditional oil samples was another finding of the present study. While about $50 \%$ of the lactic acid isolated from Brazilian cheese belonged to Enterococcus species, four strains of $E$. hirae were isolated from fermented cheese by Xinjisng in another study $(27,36)$. The genus Enterococcus has many species, but E. faecalis, E. faecium, and E. lactis, and more recently $E$. hirae and $E$. dorans have been studied as probiotic species. A strain of Enterococcus, named E. faecium K77D, is used commercially as a starter (37-40). L. rhamnosus has been extensively studied. This bacterium can survive even in difficult conditions of the digestive system and urinary tract (41). Non-starter LAB are traditionally used to improve organoleptic properties of products. Non-starter bacteria such as some genus of Lactobacillus and Enterococcus are resistance to heat and extreme conditions. Guessa et al. predominantly isolated Lactobacillus, Enterococcus, Lactococcus and Lecconestoc species from a traditional butter called "Dhan" (42). Enterococci are not used as starter in food preparation, but they can be used as dietary supplements in pharmaceutical preparation. Nevertheless, the use of Enterococci as probiotics has remained unknown in food safety. It must be noted that Enterococci have a positive role in traditionally fermented foods $(43,44)$.

\section{Conclusion}

Various species of Lactobacillus and other lactic acid bacteria were isolated and identified from traditional diary products using culture and 16SrRNA gene sequencing, in this study. L. delbruekii, L. helveticus and $L$. fermentum are a group of thermophilic bacteria 
used as starters at high temperatures. Due to their ability to tolerate higher temperatures, in our study, these species were isolated from all three kinds of samples including Kermanshahi traditional oil that receives intense heat in the production process. These species have more suitable proteolytic properties and more beneficial biological effects than other Lactobacillus species. L. fermentum, was isolated from all three kinds of samples, traditional yogurt, butter and oil and is widely used in the production of fermented food. In this study, a variety of potentially probiotic bacteria were isolated from all three samples, but many are probably killed by high temperatures during the preparation and production of traditional oil. However, findings of the present study showed that some species were able to tolerate high heat and harsh conditions, and were able to

\section{Referance}

1. Angmo K, Kumari A, Bhalla TC. Probiotic characterization of lactic acid bacteria isolated from fermented foods and beverage of Ladakh. LWT-food Sci Technol. 2016;66:428-35. [DOI:10.1016/i.lwt.2015.10.057]

2. Fguiri I, Ziadi M, Atigui M, Ayeb N, Arroum S, Assadi $\mathrm{M}$, et al. Isolation and characterisation of lactic acid bacteria strains from raw camel milk for potential use in the production of fermented Tunisian dairy products. Int J Dairy Technol. 2016;69(1):103-13.

[DOI:10.1111/14710307.12226]

3. Lim S-M, Im D-S. Screening and characterization of probiotic lactic acid bacteria isolated from Korean fermented foods. J Microbiol Biotechnol. 2009;19(2):178-86. [DOI:10.4014/jmb.0804.269] [PMID]

4. Bhattarai RR, Gautam N, Nawaz MA, Das SKL. Isolation and identification of dominant lactic acid bacteria from dahi: an indigenous dairy product of Nepal Himalayas. J Microbiol, Biotechnol Food Sci. 2016;5(4):358. [DOI:10.15414/jmbfs.2016.5.4.358-363]

5. Tabatabaei Yazdi F, Alizadeh Behbahani B, Mohebbi M, Mortazavi SA, Ghaitaranpour A. Identification of lactic acid bacteria isolated from Tarkhineh, a traditional Iranian fermented food. Sci J Microbiol. 2012;1.

6. Lourens-Hattingh A, Viljoen BC. Yogurt as probiotic carrier food. Int dairy J. 2001;11(1-2):117. [DOI:10.1016/S0958-6946(01)00036-X]

7. Adolfsson O, Meydani SN, Russell RM. Yogurt and gut function. Am J Clin Nutr. 2004;80(2):245-56. [DOI:10.1093/ajcn/80.2.245] [PMID] survive and replicate in traditional oil. Therefore, isolation and identification of various potentially probiotic bacteria from different traditional dairy products can help preserve these bacteria to be used in fermented and functional food products.

\section{Acknowledgment}

The authors of the article express their gratitude to the adjutancy Research and Technology of Kermanshah University of Medical Sciences for financing this research project with the tracking code 93323.

\section{Conflict of Interest}

There is no Conflict of Interest.

8. Ghafoorunissa G. Role of trans fatty acids in health and challenges to their reduction in Indian foods. Asia Pacific J Clin Nutr. 2008;17:212-5.

9. Ahmadiasl $\mathrm{N}$, Alipour MR, Andalib S, Ebrahimi $\mathrm{H}$. Effect of ghee oil on blood fat profile and passive avoidance learning in male rats. 2008; 7-10.

10. Bahrami GR, Rahi H, Pyravi-Vanak Z. Change in fatty acids composition of milk products during the traditional Ghee-making process. J Kerman Uni Med Sci. 2000;7(1):14-9.

11. Ritchie LE, Burke KF, Garcia-Mazcorro JF, Steiner JM, Suchodolski JS. Characterization of fecal microbiota in cats using universal 16S rRNA gene and group-specific primers for Lactobacillus and Bifidobacterium spp. Vet microbiology. 2010;144(1-2):140-6.

[DOI:10.1016/j.vetmic.2009.12.045] [PMID]

12. Song D, Ibrahim S, Hayek S. Recent application of probiotics in food and agricultural science. Probiotics. 2012; 3;10:1-34.. [DOI:10.5772/50121]

13. Araújo EA, dos Santos Pires AC, Pinto MS, Jan G, Carvalho AF. Probiotics in dairy fermented products. Rijeja: Intech. 2012; 3:129-48.

14. Narimani, T., Tarinejad, A., Hejazi, M. Isolation and identification of lactic acid bacteria from traditional dairy products of Kleibar, Heris and Varzaghan. Food Hyg, 2013; 3(3 (11)): 23-37.

15. Ebrahimi MT, Ouweh AC, Hejazi MA, Jafari P. Traditional Iranian dairy products: A source of potential probiotic lactobacilli. African J Microbiol Res. 2011;5(1):20-7.

16. Yu J, Wang $H$, Zha $M$, Qing $Y$, Bai $N$, Ren $Y$, et al. Molecular identification and quantification of 
lactic acid bacteria in traditional fermented dairy foods of Russia. J Dairy Sci. 2015;98(8):5143-54. [DOI:10.3168/jds.2015-9460] [PMID]

17. Sadeghi A, Ebrahimi M. Isolation, molecular identification and evaluation of the probiotic properties of dominant Lactobacillus in whole wheat sourdough. J Microb World. 2016 Aug $1 ; 9(2): 133-44$.

18. Kia Dalirif F, Sadeghi A, Khomeiri M, Kashaninejad M, Aalami M. Evaluating the antimicrobial properties of Lactobacillus brevis isolated from whole barley sourdough. Food Science and Technology. 2018;15(2):247-57.

19. Jamaly N, Benjouad A, Bouksaim M. Probiotic potential of Lactobacillus strains isolated from known popular traditional Moroccan dairy products. $\mathrm{Br}$ Microbiol Res J. 2011;1(4):79. [DOI:10.9734/BMRJ/2011/438]

20. Chen T, Wang L, Li Q, Long $Y$, Lin $Y$, Yin J, et al. Functional probiotics of lactic acid bacteria from Hu sheep milk. BMC Microbiol. 2020;20(1):1-12. [DOI:10.1186/s12866-020-01920-6] [PMID] [PMCID]

21. Sabir F, Beyatli Y, Cokmus C, Onal-Darilmaz D. Assessment of potential probiotic properties of Lactobacillus spp., Lactococcus spp., and Pediococcus spp. strains isolated from kefir. J Food Sci. 2010;75(9):M568-M73. [DOI:10.1111/j.1750-3841.2010.01855.x] [PMID]

22. Masuda T, Kimura M, Okada S, Yasui $H$. Pediococcus pentosaceus Sn26 inhibits IgE production and the occurrence of ovalbumininduced allergic diarrhea in mice. Biosci, Biotechnol, Biochem. 2010:0912261784-. [DOI:10.1271/bbb.90656] [PMID]

23. Dorri K, Namdar N, HemayatkhahJahromi V. Isolation of lactobacilli from dairy products and their effects on the main pathogenic bacteria in stomach and intestine. Med Lab J. 2013 Apr $10 ; 7(1): 22-8$.

24. Arqués JL, Rodríguez E, Langa S, Landete JM, Medina M. Antimicrobial activity of lactic acid bacteria in dairy products and gut: effect on pathogens. BioMed Res Int. 2015;2015. [DOI:10.1155/2015/584183] [PMID] [PMCID]

25. Vélez MP, Hermans K, Verhoeven $T$, Lebeer $S$, Vanderleyden J, De Keersmaecker S. Identification and characterization of starter lactic acid bacteria and probiotics from Columbian dairy products. J Appl Microbiol. 2007;103(3):666-74. [DOI:10.1111/i.13652672.2007.03294.x] [PMID]
26. The isolation of lactic acid bacteria from local dairy products of Gorgan township with the ability to inhibit the growth of some gastrointestinal pathogens. Koohsari $\mathrm{H}$, Rashti Z, Arab Sh. J Food Microbiol. 2019;6(3):22-36.

27. Azat R, Liu Y, Li W, Kayir A, Lin D-b, Zhou W-w, et al. Probiotic properties of lactic acid bacteria isolated from traditionally fermented Xinjiang cheese. J Zhejiang Uni Sci B. 2016;17(8):597-609. [DOI:10.1631/jzus.B1500250] [PMID] [PMCID]

28. Kiran KA, Appaiah KA, Appaiah S. Extension of Shelf Life of Curd--An Indian Fermented Milk by Using A New Isolate of Brevibacillus Brevis Strain as Starter Culture. Innov Rom Food Biotechnol. 2012 Mar 1(10).

29. Najafi T, Eghtesadi S, Rezaei M, Daneshvar K. The effect of Kermanshahi animal oil on serum lipid profile in healthy men. Behbood J. 2010;14(4).

30. Idoui T, Boudjerda J, Leghouchi E, Karam NE. Lactic acid bacteria from" Sheep's Dhan", a traditional butter: Isolation, identification and major technological traits. Grasas Aceites. 2009 Jun 30;60(2):177-83. [DOI:10.3989/gya.085408]

31. Sengun IY, Nielsen DS, Karapinar M, Jakobsen M. Identification of lactic acid bacteria isolated from Tarhana, a traditional Turkish fermented food. Int J food Microbiol. 2009;135(2):105-11. [DOI:10.1016/j.ijfoodmicro.2009.07.033] [PMID]

32. Guarner F, Perdigon G, Corthier G, Salminen S, Koletzko B, Morelli L. Should yoghurt cultures be considered probiotic? Br J Nutr. 2005;93(6):7836. [DOI:10.1079/BJN20051428] [PMID]

33. Tsai C-C, Chou L-C, Lai S-E, Huang C-C. Effect of cholesterol lowering multiplex lactic acid bacteria on lipid metabolism in a hamster model. African J Microbiol Res. 2016;10(20):708-16. [DOI:10.5897/AJMR2015.7719]

34. MATAR C, VALDEZ JC, MEDINA M, RACHID M, PERDIGON G. Immunomodulating effects of milks fermented by Lactobacillus helveticus and its non-proteolytic variant. J Dairy Res. 2001;68(4):601-9. [DOI:10.1017/S0022029901005143] [PMID]

35. Garsa AK, Kumariya R, Sood SK, Kumar A, Kapila S. Bacteriocin production and different strategies for their recovery and purification. Probiotics Antimicrob Proteins. 2014 Mar 1;6(1):47-58. [DOI:10.1007/s12602-013-9153-z] [PMID]

36. Silva LF, Casella T, Gomes ES, Nogueira MCL, De Dea Lindner J, Penna ALB. Diversity of lactic acid bacteria isolated from Brazilian water buffalo 
mozzarella cheese. J Food Sci. 2015;80(2):M411M7. [DOI:10.1111/1750-3841.12771] [PMID]

37. Adnan M, Patel M, Hadi S. Functional and health promoting inherent attributes of Enterococcus hirae F2 as a novel probiotic isolated from the digestive tract of the freshwater fish Catla catla. PeerJ. 2017;5:e3085. [DOI:10.7717/peerj.3085] [PMID] [PMCID]

38. Li B, Zhan M, Evivie SE, Jin D, Zhao L, Chowdhury $S$, et al. Evaluating the safety of potential probiotic Enterococcus durans KLDS6. 0930 using whole genome sequencing and oral toxicity study. Front Microbiol. 2018;9:1943. [DOI:10.3389/fmicb.2018.01943] [PMID] [PMCID]

39. Hassanzadazar H, Ehsani A, Mardani K. Antibacterial activity of Enterococcus faecium derived from Koopeh cheese against Listeria monocytogenes in probiotic ultra-filtrated cheese. In: Veterinary research forum: an international quarterly journal 2014 (Vol. 5, No. 3, p. 169). Faculty of Veterinary Medicine, Urmia University, Urmia, Iran.

40. Torres-Llanez $M$, Vallejo-Cordoba B, Díaz-Cinco M, Mazorra-Manzano M, González-Córdova A.
Characterization of the natural microflora of artisanal Mexican Fresco cheese. Food Control. 2006;17(9):683-90.

[DOI:10.1016/j.foodcont.2005.04.004]

41. Beerepoot M, Ter Riet G, Nys S. Lactobacilli versus antibiotics to prevent urinary tract infections: a randomized, double-blind, noninferiority trial in postmenopausal women. Arch Intern Med. 2012;172(9):704-12.

[DOI:10.1001/archinternmed.2012.777] [PMID]

42. Bettache G, Fatma A, Miloud H, Mebrouk K. Isolation and identification of lactic acid bacteria from Dhan, a traditional butter and their major technological traits. World Appl Sci J. 2012;17(4):480-8.

43. Franz CM, Huch M, Abriouel H, Holzapfel W, Gálvez A. Enterococci as probiotics and their implications in food safety. Int J Food Microbiol. 2011;151(2):125-40.

[DOI:10.1016/i.ijfoodmicro.2011.08.014] [PMID]

44. Franz CM, Stiles ME, Schleifer KH, Holzapfel WH. Enterococci in foods-a conundrum for food safety. Int J Food Microbiol. 2003;88(2-3):105-22. [DOI:10.1016/S0168-1605(03)00174-0] 


$$
\begin{aligned}
& \text { مجله ميكروبشناسى يزشكى ايران }
\end{aligned}
$$

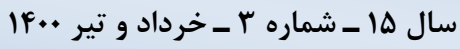

$$
\begin{aligned}
& \text { Journal homepage: www.ijmm.ir }
\end{aligned}
$$

\section{باكترى هاى داراى يتاسيل بروبيوتيك جداشده از مراحل آماده سازى روغن كرمانشاهى}



' أ. مركز تحقيقات باروى و نابارورى، دانشكدة يزشكى، دانشكاه علوم يزشكى كرمانشاه، كرمانشاه، ايران

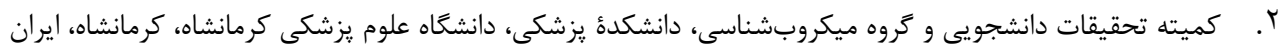



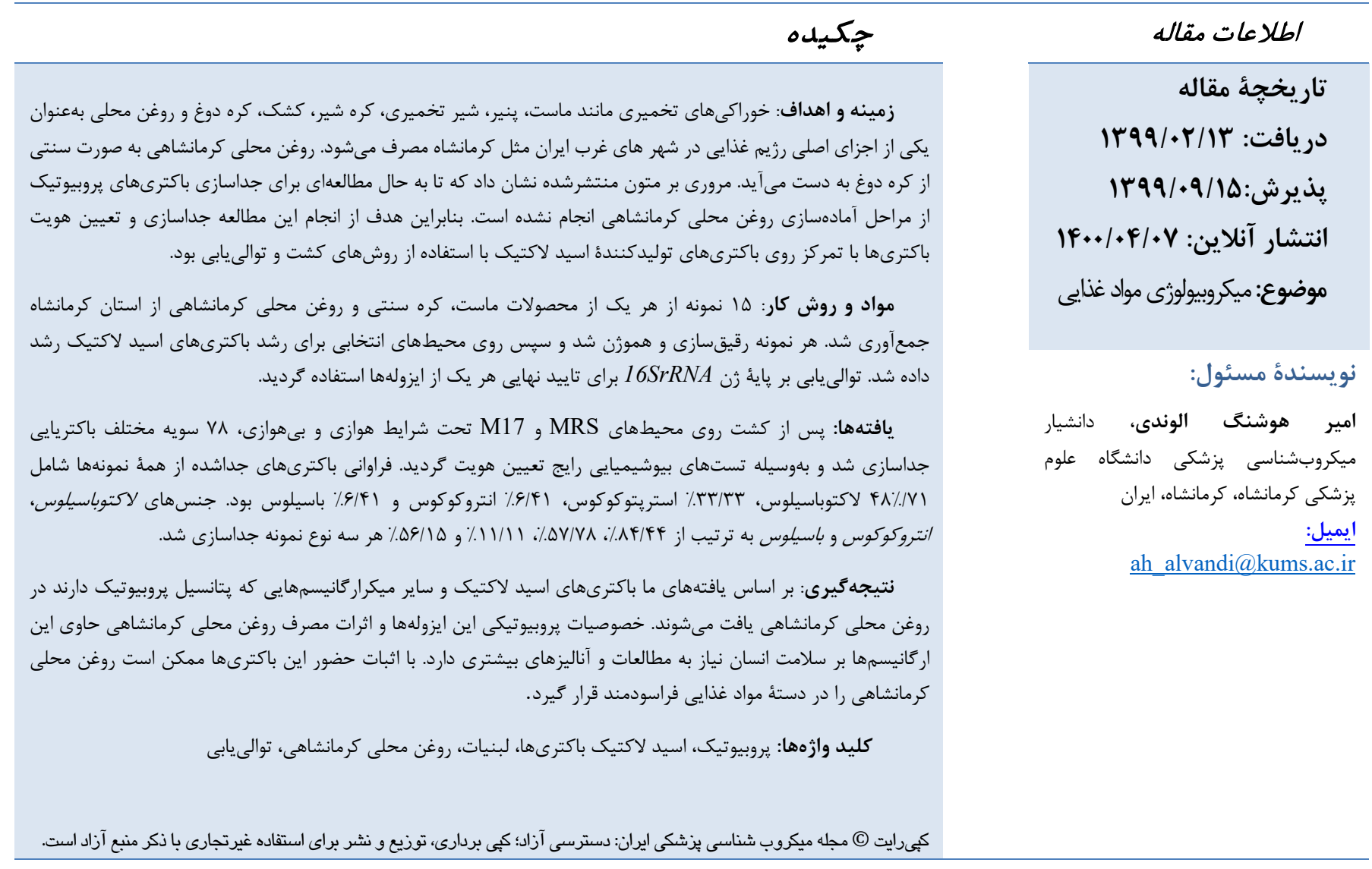

